\section{E \\ Entrepreneurial Business and Economics Review}

2015, Vol. 3, No. 4
OPEN

ACCESS

DOI: 10.15678/EBER.2015.030401

\title{
Editorial: Dilemmas of Modern Economy and Business
}

Various dilemmas concerning modern economy and business have been in the focus of scientific discussion in recent years (Klich, 2013; Renko \& Knezevic, 2013; Szarucki, 2013; Agrawal \& Gugnani, 2014; Pardhasaradhi \& Grace, 2015). In modern economy, not only researches but corporations face complex economic and business dilemmas in their daily routine. The Joint Research Centre of the European Commission addresses key economic challenges by stimulating innovations, sustainability policies, social and environmental responsibilities. These challenges require the mobilization of significant resources by science, innovation and regional policy makers and scientific communities across Europe (EUA, 2014). Broader scientific discussions are crucial for the success of the Europe 2020 strategy for smart, sustainable and inclusive growth.

According to the Global Risks Report 2015, the biggest threat to world stability in the next 10 years arise from the four most serious economic risks. These are high structural unemployment or underemployment, energy price shock, critical information infrastructure breakdown and fiscal crises. We continuously agree that innovation is critical to global prosperity (WEF, 2015). Currently, the internationalisation of family businesses is an increasingly important research area. Substantial numbers of FBs are forced to expand into foreign markets in order to survive and grow in the competitive environment (Daszkiewicz $\&$ Wach, 2014). The roles of business angels are especially important taken both decreasing the levels of formal venture capital investment and growing average amount of individual deals. Angel investors are the key players in generating high-growth companies, essential to regional economic development. As a result, they have attracted the attention of policy makers (Rostamzadeh et. al., 2014).

Consequently, this issue of EBER concentrates on the current dilemmas of modern economy and business, particularly dealing with the Baltic States, Slovenia and Poland. Five out of eight articles published in this issue are research papers, two are conceptual papers, while one is a literature review.

This issue starts with three papers investigating the emergence and determinants of born global enterprises, comparing theories of firm internationalisation as well as some specific strategies of enterprise internationalisation. Second of the issue includes five articles dealing with issues related to social entrepreneurship, social and environmental initiatives, decision-making in business negotiations, public innovation assessment and sustainability of pension systems.

First paper, Entrepreneur-related Constructs Explaining the Emergence of Born Global Firms: A Systematic Literature Review, written by Elena Pawęta presents the results of an extensive literature investigation aimed at systematising the knowledge on entrepreneurrelated factors influencing the growth of born global enterprises. The author attempts at 
developing a conceptual framework, which can serve as basis for further growth of international entrepreneurship theory and research.

Second paper, Incremental versus Rapid Internationalisation of Firms: Results of Exploratory Investigation from Poland, prepared by Krzysztof Wach aims at exploring and discussing the speed of enterprises' internationalisation within the lenses of two main theoretical perspectives. The author has investigated the research problem on the example of 355 enterprises from Poland concentrating on two main elements: strategic thinking and familness.

Third article, Internationalisation at Home: Exploiting the Potential of the Non-nationals' and Expatriates' Community, by Andreja Jaklič and Paraskevi Karageorgu investigates first-time internationalisation strategy of an organisation without crossing the country borders while dealing with non-nationals in its home market. According to the results the non-nationals' and expatriates' community, as frequently neglected market segment, has a positive influence on enterprise performance. Moreover its growing potential in some European cities was highlighted.

Social Problems as Sources of Opportunity: Antecedents of Social Entrepreneurship Opportunities, by Agnieszka Żur is a conceptual one, where the author tries to find answers to several important questions related to theory of social entrepreneurship. The paper concentrates on the opportunity-based view of social entrepreneurship with regard to its application to explore social entrepreneurship activity.

Children-Engaging Social and Environmental Initiatives as Determinants of Corporate Reputation by Ingrida Šmaižienè aims at exploring children-engaging social and green initiatives as determinants of corporate reputation. The outcomes of the conducted research have proven that that consumers are likely to agree that enterprises that utilise childreninvolving corporate social responsibility initiatives lead to the development of children as responsible citizens. Moreover, engaging children in corporate social and environmental activities can be perceived as a determinant of corporate reputational risk and not only as an act of being a good citizen.

The Use of Game Theory for Making Rational Decisions in Business Negotiations by Kęstutis Peleckis presents a critical literature review on game theory and its applicability for rational decision-making in negotiations, aiming at a model proposition supporting strategic decisions in negotiations. Moreover it also demonstrates a model which combines the game theory approach with heuristic algorithms in order to better reflect the specifics of negotiations. This tool seems to be useful for better understanding of the strategic management of negotiating processes and can be applied to support strategic decision making in negotiations.

Public Innovation Support Index for Impact Assessment in the European Economic Area by Mantas Vilys, Artūras Jakubavičius and Eigirdas Žemaitis, deals with exploring conceptual frameworks for evaluation of the influence of public innovation support systems for innovations' development in the European Economic Area. Based on the research results, the authors have proposed their own original model for the assessment of public innovation support system. The findings confirm the utility of the suggested model for the description and impact assessment of public innovation support systems in the European Economic Area. 
The final paper, Sustainability of Pension Systems in the Baltic States, prepared by Olga Rajevska identifies how the concept of sustainability is ensured in the pension systems, as well as its implications to the performance of pension schemes in Estonia, Latvia and Lithuania. This empirical paper presents the impact of differences at policy formulation stage and in the very design of pension schemes on pension system sustainability in countries with a very similar initial conditions and socio-economic environment.

We do believe that in this issue everyone can find something of interest to his or her scientific curiosity that would be worth of further exploration. Moreover, we are glad to inform our current and potential authors about the success of our Journal. It was highly rated by the Polish Ministry of Science and Higher Education during the assessment of scientific journals, which was published on 23 December 2015. According to the assessment Entrepreneurial Business and Economic Review is now worth 12 points (on the scale from 1 to 15) with regard to the Ministry regulations. We hope that this excellent evaluation will serve as an additional stimuli and inspiration for authors to submit original high quality scientific publications.

\section{Jelena Stankevičienè \\ Marek Szarucki \\ Issue Thematic Editors}

\section{REFERENCES}

Agrawal, S., \& Gugnani, R. (2014). Creating successful business model: Lessons for social entrepreneurship. International Journal of Entrepreneurship and Innovation Management, 18(5-6), 438445.

Daszkiewicz, N., \& Wach, K. (2014). Motives for going international and entry modes of family firms in Poland. Journal of Intercultural Management, 6(2), 5-18.

European University Association (EUA). (2014). Report on Joint EUA-REGIO/JRC Smart Specialisation Platform Expert Workshop: The Role of Universities In Smart Specialisation Strategies, Brussels, Belgium. Retrieved on December 22, 2015 from http://www.eua.be/Libraries/publication/EUA_Seville_Report_web.pdf?sfvrsn=2

Klich, J. (2013). Editorial: Modern Challenges for International Business in Europe. Entrepreneurial Business and Economics Review, 1(2), 5-6.

Pardhasaradhi, R., \& Grace (2015). Contemporary business challenges - Strategies for global competitiveness. International Journal of Applied Business and Economic Research, 13(3), 10051013.

Rostamzadeh, R., Ismail, K., \& Zavadskas, E.K. (2014). Multi criteria decision making for assisting business angels in investments. Technological and Economic Development of Economy, 20(4), 696-720.

Renko, S., \& Knezevic, B. (Eds.). (2013). Challenges for the Trade of Central and Southeast Europe (International Business and Management, Volume 29), Bingley: Emerald Group Publishing Limited.

Szarucki, M. (2013). Editorial: Modern Challenges for Business and Economy in CEE Countries. Entrepreneurial Business and Economics Review, 1(4), 5-6.

World Economic Forum (WEF). (2015). Global Risks 2015, 10th Edition. REF: 090115. 